V. N. Fedorov ${ }^{1}$, candidate of technical sciences, V. V. Kikot ${ }^{2}$, student, N. I. Shtefan ${ }^{3}$, candidate of technical sciences

\title{
ON USING THE ROTOR ACCELERATION MODE TO INCREASE THE ACCURACY OF A TWO-STAGE GYROCOMPASS
}

Завдання забезпечення високої точності вимірювання орієнтації рухомих об'єктів було і залишається надзвичайно актуальним. Для визначення положення площини географічного меридіана під час старту рухомих об'ктів використовуються високотчні гірокомпаси - триступеневі та двоступеневі. У статті розглянуто двоступеневий гірокомпас із жорстким торсійним підвісом рухомої частини. «Старіння матеріалу» торсіонів, вплив на них температури тощо, призводить до неконтрольованої зміни кутової жорсткості торсіонів, що, у свою чергу, призводить до появи помилки у визначенні положення меридіана.

Запропоновано метод визначення положення меридіана за умов, коли кутова жорсткість торсіонів - невідома. Метод передбачає спостереження за рухом гіроскопа у режимі, коли кінетичний момент змінюється за лінійним законом (ротор розганяється).

У результаті мінімізації розбіжності реального руху гірокомпаса і руху його математичної моделі знаходяться «найкраща оцінка» параметра, що характеризує положення меридіана, і «найкраща оцінка» кутової жорсткості торсіонів в даному вимірюванні. Розглянуто результати моделювання відповідних алгоритмів обробки інформації. Вказані переваги запропонованої методики в порівнянні з традиційними.

Рассматривается методика применения двухстепенного гирокомпаса в условиях, когда угловая жесткость торсионов подвеса - неизвестна. Методика предполагает сравнение реального движения гирокомпаса в режиме линейного разгона ротора с математической моделью этого движения. В результате минимизации несовпадения двух указанных движений находятся «наилучшая оценка» начального отклонения оси ротора гирокомпаса от плоскости меридиана и «наилучшая оценка» угловой жесткости торсионов в данном измерении. Рассмотрены результаты моделирования соответствующих алгоритмов обработки информации.

\section{Introduction}

In geodesy, cartography, in the transport sector and military affairs, instruments that made it possible to determine the position of the axes of the geographical coordinate system at the place of measurements were widely used.

\footnotetext{
${ }^{1}$ Igor Sikorsky Kyiv polytechnic institute

${ }^{2}$ Igor Sikorsky Kyiv polytechnic institute

${ }^{3}$ Igor Sikorsky Kyiv polytechnic institute
} 
In peacetime the speed and accuracy of obtaining information from these devices influence the quality of the performed work and their productivity, whereas in combat situation these features can preserve the personnel life while carrying out the tasks. To improve the accuracy of the above mentioned meters, a fairly large number of methods have been proposed, most of which involve the presence of two identical devices with the kinetic moment vectors directed oppositely [1], or conducting software turns of the device's body during measurements $[2,3]$. These methods require the design refinement of devices, which is their «minus». Recently, the so-called «algorithmic methods» for increasing the accuracy of instruments, involving the observation of the movement of a sensitive element of a device with subsequent mathematical processing of information have been widely used [4]. In order to significantly reduce the measurement time, it was proposed [5] to use information on the movement of the sensitive element of the three-degree ground pendulum gyrocompass obtained during acceleration of its rotor. At the same time, it is possible to simultaneously «evaluate» the constant uncontrolled harmful moment acting around the axis of suspension of the sensing element.

Two-stage terrestrial gyrocompasses have an advantage over three-stage gyrocompasses due to the smaller period of free oscillations. The use of twostage gyrocompasses with the suspension of the moving part on rigid torsion bars leads to a further reduction in the period of free oscillations, however, the presence of an error related to the uncontrolled change in the angular rigidity of torsion bars in time inhibits the widespread use of this device.

\section{Formulation of the problem}

The purpose of this article is to develop algorithms for processing of information about the movement of a sensitive element of a two-stage gyrocompass in the mode of acceleration of its rotor, allowing one to determine both the azimuth of the north direction and the angular stiffness of the torsion bars at the time of measurement, which will significantly increase the accuracy and speed of the device.

\section{Statement of the main research material}

Two degrees gyrocompass is essentially an angular velocity sensor, responsive to the horizontal component $\Omega_{\mathrm{G}}$ of the Earth angular velocity, provided that the axis of suspension of the device exhibited at locations vertically. In case if the suspension device is made on the rigid torso tries, gyroscopic moment $H \Omega_{G} \alpha$ ( $H$ is a kinetic moment gyro, $\alpha$ is a small d-axis deviation angle of the rotor of the geographic meridian plane) is balanced by elastic torsions point $k\left(\alpha-\alpha_{0}\right)$, where $k$ is the angular torsion stiffness, $\alpha_{0}$ is the azimuth axis gyro rotor flexbeam when is not twisted. At the end of the 
transition process, the azimuth of the steady-state position of the rotor axis $\alpha_{\text {set }}$ can be determined as

$$
\alpha_{s e t}=k\left(\alpha_{s e t}-\alpha_{0}\right) H^{-1} \Omega_{G}^{-1} .
$$

As seen from (1), the accuracy of the position determining of geographic meridian depends on the precision reference latitude measuring point, stability of the angular momentum, the accuracy of measurement of the angle of the gate of the gyroscope and the angular reference of torsions accuracy. It is nonstability of the torsion rigidity $\Delta k$, resulted from «aging of the torsion material», temperature affecting etc. leads to an error

$$
\Delta \alpha_{\text {set }}=\Delta k\left(\alpha_{\text {set }}-\alpha_{0}\right) H^{-1} \Omega_{G}{ }^{-1},
$$

which is dominant in the operation of a two-stage gyrocompass [6, 7].

The article discusses the technique for determining the plane of the geographic meridian with a two-stage gyrocompass in the case when the angular rigidity of the torsion bars is not known in advance. The technique involves observation of the movement of the main axis of the gyroscope in the mode of the kinetic momentum change according to the law

$$
H=H+h t,
$$

where $h$ is the rate of kinetic moment change, $H_{0}$ is the initial value of the angular momentum, $t$ is current time, followed by comparing the actual curve of the azimuth movement of the movable part of the device and its mathematical model, made by the method of least squares. The «best estimate» of the azimuth $\hat{\alpha}_{0}$ of the initial position of the rotor axis obtained due to this method will be the answer to the task of the gyrocompass to find the position of the meridian $[8,9]$, and the «best estimate» of the angular stiffness $\hat{k}$ of the torsion bars will correspond to the rigidity value in this launch.

The equation of motion of a two-stage gyrocompass at small angles of deviation from the plane of the meridian has the form [10]:

$$
I \ddot{\alpha}+H \Omega_{G} \alpha+k\left(\alpha-\alpha_{0}\right)=0,
$$

where $I$ is the axial moment of inertia of the moving part of the device. Taking into account (2), equation (3) can be written as follows:

$$
\ddot{a}+(A+B t) a=D \text {, }
$$

where

$$
A=\left(H_{0} \Omega_{G}+k\right) I^{-1} ; \quad B=h \Omega_{G} I^{-1} ; \quad D=k \alpha_{0} I^{-1} .
$$

A new independent variable $z$ is introduced

$$
z=\frac{2}{3 B}(A+B t)^{\frac{3}{2}}
$$

Taking into account (6), level (4) takes the form

$$
z^{2} \alpha^{\prime \prime}+\frac{1}{3} z \alpha^{\prime}+z^{2} \alpha=D(1,5 B)^{-\frac{2}{3}} z^{\frac{4}{3}},
$$


where $\alpha^{\prime}=\frac{d \alpha}{d z} ; \alpha^{\prime \prime}=\frac{d^{2} \alpha}{d z^{2}}$, and its solution can be written as follows [11]:

$$
\alpha=z^{\frac{1}{3}} I_{\frac{1}{3}}(z)+z^{\frac{1}{3}} Y_{\frac{1}{3}}(z)
$$

where $Y_{1 / 3}(z)$ and $I_{1 / 3}(z)$ are Bessel functions of the first and the second kind of order $« 1 / 3 »$.

Amateur solution, found using the procedure of arbitrary constants variations, with the recurrence relations for Bessel functions is given by:

$$
\alpha_{\text {fractional }}=\frac{\pi}{2} D(1,5 B)^{-\frac{2}{3}}\left[\int_{0}^{z} z^{2} I_{\frac{1}{3}}(z) d z\right] z^{\frac{1}{3}} Y_{\frac{1}{3}}(z)-\frac{\pi}{2} D(1,5)^{-\frac{2}{3}}\left[\int_{0}^{z} z^{2} Y_{\frac{1}{3}}(z) d z\right] z^{\frac{1}{3}} I_{\frac{1}{3}}(z) .
$$

Therefore, the general solution of equation (7) can be written as follows:

$$
\alpha=C_{1} z^{\frac{1}{3}} I_{\frac{1}{3}}(z)+C_{2} z^{\frac{1}{3}} Y_{\frac{1}{3}}(z)-N\left[\int_{0}^{Z} z^{2} Y_{\frac{1}{3}}(z) d z\right] z^{\frac{1}{3}} I_{\frac{1}{3}}(z)+N\left[\int_{0}^{Z} z^{2} I_{\frac{1}{3}}(z) d z\right] z^{\frac{1}{3}} Y_{\frac{1}{3}}(z) .
$$

where $N=\frac{\pi}{2} D(1,5 B)^{-\frac{2}{3}}$.

To find the integration constants $C_{1}$ and $C_{2}$, we introduce the initial conditions:

$$
\begin{aligned}
& t=0 \rightarrow \dot{\alpha}(0)=\dot{\alpha}_{0} ; \alpha(0)=\alpha_{0} \\
& t=0 \rightarrow z(t=0)=z_{0}=\frac{2}{3 B} A^{\frac{3}{2}} \\
& \dot{\alpha}=\alpha^{\prime}(1,5 B z)^{\frac{1}{3}} \rightarrow \dot{\alpha}_{0}=\alpha_{0}^{\prime}\left(1,5 B z_{0}\right)^{\frac{1}{3}}
\end{aligned}
$$

in which the general solution of equation (7) has the form:

$$
\begin{aligned}
\alpha & =2 N\left[-E\left(z_{0}, z\right) z^{\frac{1}{3}} I_{\frac{1}{3}}(z)+F\left(z_{0}, z\right) z^{\frac{1}{3}} Y_{\frac{1}{3}}(z)\right]+ \\
& +\alpha_{0} \cdot \frac{\pi}{2}\left(z \cdot z_{0}^{2}\right)^{\frac{1}{3}}\left[I_{\frac{1}{3}}(z) Y_{-\frac{2}{3}}\left(z_{0}\right)-Y_{\frac{1}{3}}(z) I_{-\frac{2}{3}}\left(z_{0}\right)\right]- \\
& -\alpha_{0}^{\prime} \cdot \frac{\pi}{2}\left(z \cdot z_{0}^{2}\right)^{\frac{1}{3}}\left[Y_{\frac{1}{3}}\left(z_{0}\right) I_{\frac{1}{3}}(z)-I_{\frac{1}{3}}\left(z_{0}\right) Y_{\frac{1}{3}}(z)\right] .
\end{aligned}
$$

Where

$$
E\left(z_{0}, z\right)=\int_{z_{0}}^{z} z^{2} Y_{\frac{1}{3}}(z) d z ; \quad F\left(z_{0}, z\right)=\int_{z_{0}}^{z} z^{2} I_{\frac{1}{3}}(z) d z
$$

Considering the fact that the observed coordinate of the gyroscope motion is the $\alpha-\alpha_{0}$ expression (11) is represented as follows: 


$$
\begin{aligned}
\alpha-\alpha_{0} & =2 N\left[-E\left(z_{0}, z\right) z^{\frac{1}{3}} I_{\frac{1}{3}}(z)+F\left(z_{0}, z\right) z^{\frac{1}{3}} Y_{\frac{1}{3}}(z)\right]+ \\
& +\alpha_{0}\left\{\frac{\pi}{2}\left(z \cdot z_{0}^{2}\right)^{\frac{1}{3}}\left[I_{\frac{1}{3}}(z) Y_{-\frac{2}{3}}\left(z_{0}\right)-Y_{\frac{1}{3}}(z) I_{-\frac{2}{3}}\left(z_{0}\right)\right]-1\right\}- \\
& -\alpha_{0}^{\prime} \cdot \frac{\pi}{2}\left(z \cdot z_{0}^{2}\right)^{\frac{1}{3}}\left[I_{\frac{1}{3}}(z) Y_{\frac{1}{3}}\left(z_{0}\right)-Y_{\frac{1}{3}}(z) I_{\frac{1}{3}}\left(z_{0}\right)\right] .
\end{aligned}
$$

The left side of equation (12) is a well-known function of time, which is the angle of rotation of the main axis in azimuth relative to the gyrocompass body. The right side of this equation is the mathematical model of the indicated motion $\left(\alpha_{M}(z)-\alpha_{0}\right)$. Then, it is necessary to find the «best» estimates of the initial parameters guided by the criterion of minimum mismatch of the azimuth motion curve and its mathematical model (the left and right side of equation (12)). It is impossible to apply the method of least squares (MLS) in its analytical form since the desired initial position of the rotor axis and angular torsion stiffness $k$ are nonlinear in the mathematical model $\left(\alpha_{M}(z)-\alpha_{0}\right)$. In this case, it is possible to use the solutions of Eq. (7) in the form of the right-hand side of dependence (12) as a mathematical model.

Another option is also possible when its differential equation (4) is accepted as a mathematical model and gyrocompass. Machine modeling of the least-squares procedure was carried out in exactly this way [12] (Fig. 1).

The differential equation (4) imitated the gyrocompass movement for the following values of input parameters:

- moment of inertia of the moving part of the device $J=1,1607 \cdot 10^{-3},\left[\mathrm{H} \cdot \mathrm{m} \cdot \mathrm{s}^{2}\right]$;

- the initial value of the angular momentum $H_{0}=0,4,[\mathrm{H} \cdot \mathrm{m} \cdot \mathrm{s}]$;

- the rate of change of the kinetic moment $h=2 \cdot 10^{-3},[\mathrm{H} \cdot \mathrm{m}]$;

- the horizontal component of the angular velocity of rotation of the Earth, corresponding to a geographical latitude of $60^{\circ}, \Omega_{G}=3,65 \cdot 10^{-5},\left[\mathrm{~s}^{-1}\right]$;

- the angular stiffness of torsion $k=2,076 \cdot 10^{-4},[\mathrm{H} \cdot \mathrm{m}]$;

- the initial deviation of the main axis of the gyrocompass from the plane of the geographical meridian $\alpha_{0}=\frac{3,69 \mathrm{pi}}{540}$, [rad] ;

- -the initial rate of deviation of the main axis of the gyrocompass from the plane of the geographic meridian $\dot{\alpha}_{0}=0$;

- integration interval $t=[0 ; 200]$, [sec];

- integration step $\Delta t=1$, [sec] . 


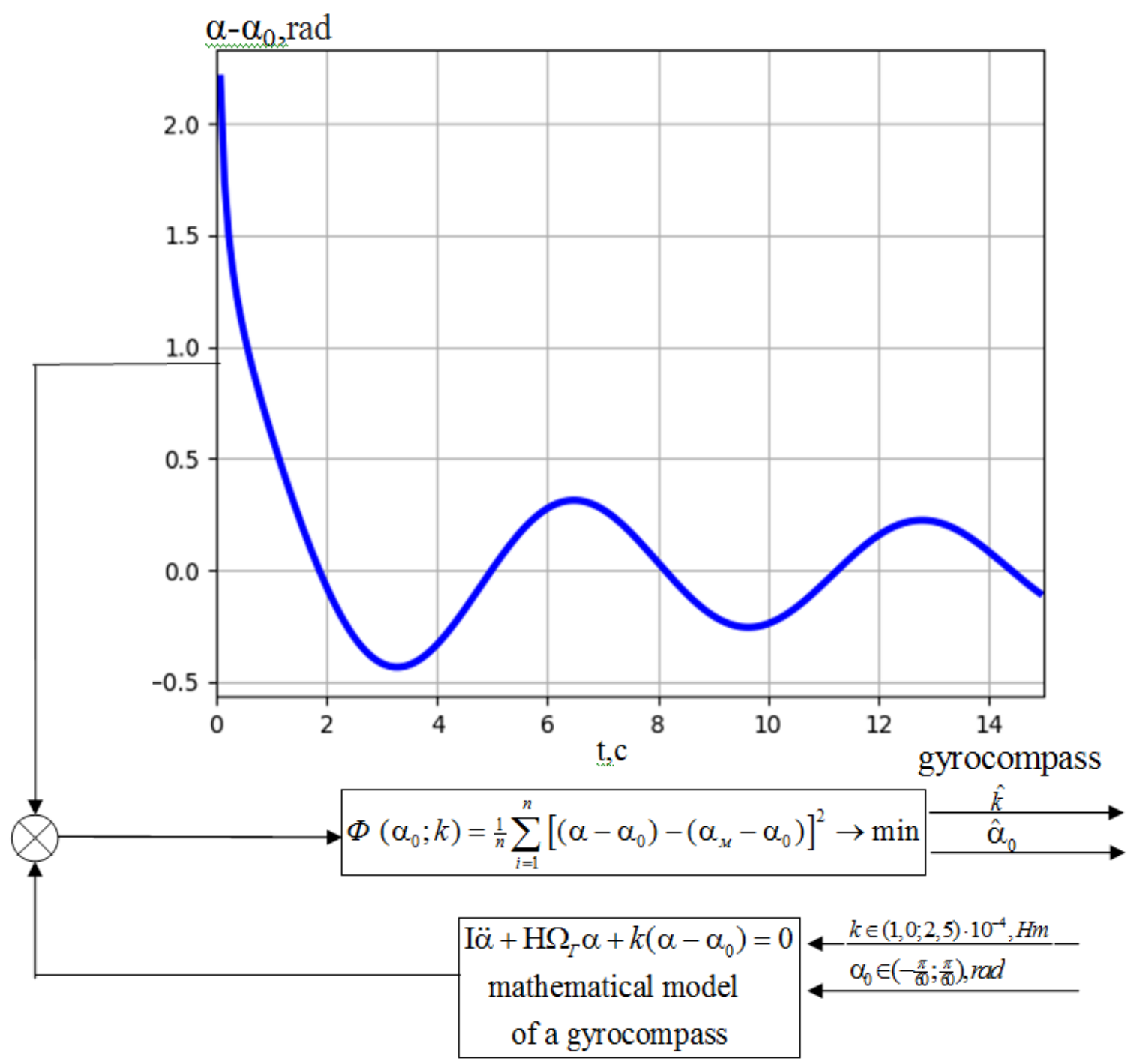

Fig. 1. Machine simulation circuit

Consequently, the real two-stage gyrocompass is represented by differential equation (4) with numerical data of the input parameters

$$
A=19,14 \cdot 10^{-2},\left[\mathrm{~s}^{-2}\right] ; B=6,29 \cdot 10^{-5},\left[\mathrm{~s}^{-3}\right] ; D=3,837 \cdot 10^{-3},\left[\mathrm{~s}^{2}\right]
$$

and initial conditions $\alpha_{0}=\frac{3,69 \pi}{540},[\mathrm{rad}]$ and $\dot{\alpha}_{0}=0$.

The mathematical model of the gyrocompass is represented by the same differential equation (4), parameters $B=6,29 \cdot 10^{-5},\left[\mathrm{~s}^{-3}\right]$ and $\dot{\alpha}_{0}=0$ which are known, and for the parameters $\left\langle\alpha_{0}\right\rangle$ and $\langle k\rangle$ their limiting values are selected :

$$
\alpha_{0} \in\left(-\frac{\pi}{60} ; \frac{\pi}{60}\right), \text { pad; } k \in(1,0 ; 2,5) \cdot 10^{-4}, H \cdot m .
$$

Further, the curve, which imitates gyrocompass (with numerical values (13)) is sequentially compared with the mathematical model of the movement as the result of machine integrating of the differential equation (4). This comparison was carried out in stages, by the method of least squares. $H$ and 
the first stage was sought «discrepancy» to $306(16 \cdot 19)$ pairs of values of parameters $\alpha_{0}$ and $k$ increments $\Delta \alpha_{0}=\frac{\pi}{540}[\mathrm{rad}]$ and $\Delta k=10^{-5},[\mathrm{H} \cdot \mathrm{m}]$. Binding $\Phi_{1}\left(\alpha_{0} ; k\right)=\frac{1}{n} \sum_{i=1}^{n}\left[\left(\alpha-\alpha_{0}\right)-\left(\alpha_{M}-\alpha_{0}\right)\right]^{2}$ with $n=200$ is presented in Table 1. As can be seen from table 1, the minimum value of the residual $\Phi_{1}\left(\alpha_{0} ; k\right)=6 \cdot 10^{-10},\left[\operatorname{rad}^{2}\right]$ takes place at, $\hat{\alpha}_{0}=3 \frac{\pi}{540} \mathrm{rad}$, and $\hat{k}=1,9 \cdot 10^{-4},[\mathrm{H} \cdot \mathrm{m}]$

Table 1.

The table «residuals». The first approximation $\Phi_{1}\left(\alpha_{0} ; k\right) \cdot 10^{-8},\left[\operatorname{rad}^{2}\right]$

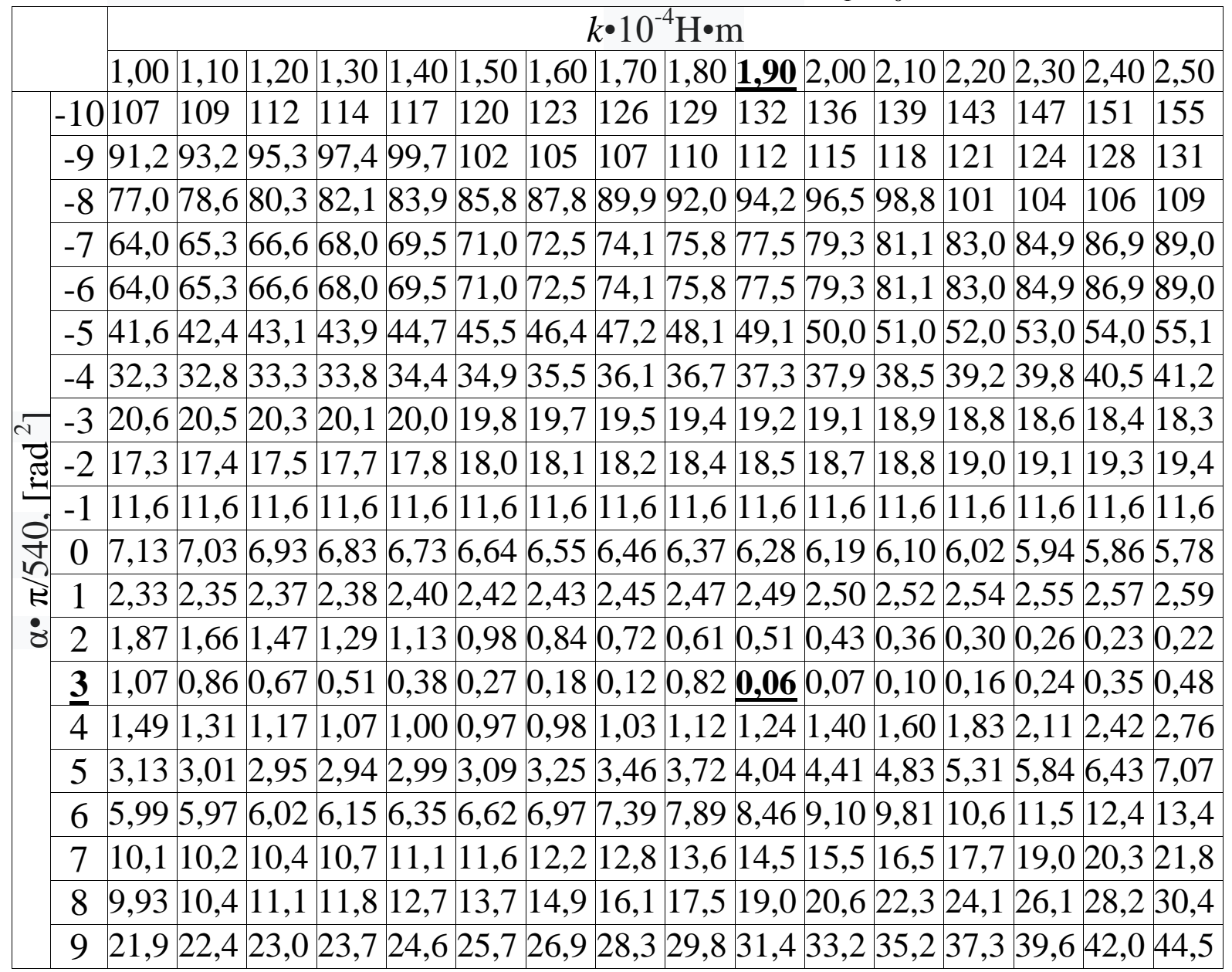

Let us choose the nearest neighborhood of the point where there is a minimum of the function $\Phi_{1}\left(a_{0} ; k\right)$ and carry out search with the minimum increments $\Delta \alpha_{0}=\frac{0,1 \pi}{540},[\mathrm{rad}] \quad$ and $\quad \Delta k=0,1 \cdot 10^{-5},[\mathrm{H} \cdot \mathrm{m}]$. The minimum value of the residual in the second approximation is $1,85 \cdot 10^{-11}$, $\operatorname{rad}^{2}$. It takes place at $\hat{\alpha}_{0}=3,7 \frac{\pi}{540},[\mathrm{rad}], \hat{k}=2,07 \cdot 10^{-4},[\mathrm{H} \cdot \mathrm{m}]$. 
The third approximation is feasible near the minimum point, again reducing the step $\Delta \alpha_{0}$ and $\Delta k$ by 10 times. The minimum value of the residuals $\Phi_{3}\left(\alpha_{0} ; k\right)=8,08 \cdot 10^{-18},\left[\operatorname{rad}^{2}\right]$, which takes place when $\hat{\alpha}_{0}=3,68 \frac{\pi}{540}$ , $\operatorname{rad}, \hat{k}=2,076 \cdot 10^{-4},[\mathrm{H} \cdot \mathrm{m}]$ is obtained. As we see residual $\Phi\left(\alpha_{0} ; k\right)$ obtained in the third approximation occurs at $\hat{\alpha}$ and $\hat{k}$, practically relevant parameters, set in the mathematical model of the gyrocompass, indicating the viability of the proposed method.

\section{Conclusions}

The article considers a two-stage gyrocompass with a suspension of the moving part made in the form of rigid torsions. It is indicated that the dominant error is the error from the instability of the angular rigidity of the torsion bars.

A method is proposed for eliminating this error, based on a joint analysis of the azimuthal movement of the gyrocompass and the movement of its mathematical model, in the mode of linear acceleration of the rotor. This approach also allows reduction of measurement time (used rotor acceleration mode, formerly ballast) in each dimension determined as the start position of the azimuth axis of the rotor, and the magnitude of angular torsion stiffness.

Algorithms for identifying the above parameters based on the least squares method have been developed. Machine modeling was performed using OLS algorithms, which confirmed the efficiency of the proposed methodology.

\section{Literature}

1. Odintsov A. A. Theory and calculation of gyroscopic devices / A. A. Odintsov - Kiev.: Vishcha school, 1985. - 392 p.

2. Zbrutsky O. V., Dovgopoliy A. S., Nesterenko O. I., Grigoryev V. M. «Gyrocompasses for navigation and guidance.» Monograph. NTUU "KPI im. Igor Sikorsky», 2017, 198 p.

3. Lysenko A. S. Self-compensating strapdown gyroclinometer for continuous shooting of wells of arbitrary orientation: dis. for the competition degrees of cand. tech. Sciences: special. 11/05/03 «Navigation Devices». - St. Petersburg, 2017 .- 170 p.

4. Rakhmuni M. Algorithmic methods to improve the accuracy of the corrected gyroscopic compass: Author. dis ... cand. tech. Sciences: 05.11.03 / M. Rakhmuni; Nat tech. University of Ukraine "Kiev. Polytechnic. Institute". - K., 2003. - 19 p.

5. Fedorov V. N. The methodology for determining the plane of the geographical meridian by the ground pendulum gyrocompass in the mode of exponential acceleration of its rotor / V. N. Fedorov, B. Yu. Ivanov, 
A. Yu. Olefir // Mechanics of gyroscopic systems. - 2015. - No. $30-$ p. 4248. DOI: http://dx.doi.org/10.20535/0203-377130201569529

6. Yulmetova O. S. Special manufacturing techniques for precision units and elements of gyroscopic devices. Textbook: O.S. Yulmetova, A. G. Shcherbak, I. B. Chelpanov. Edited by B. A. Valetova - St. Petersburg: ITMO University, 2017.- $131 \mathrm{p}$.

7. Matveev V. A. A gyroscope is simple / V. A. Matveev. - M.: Publishing House of MSTU N. E. Bauman, 2012.- 191 p.

8. Roitenberg Ya. N. About some indirect methods of obtaining information about the position of a controlled system in phase space / Ya. N. Roitenberg // PMM.-1961.- t.KhKhU, issue 3, p. 440-444.

9. Sorokin V. N. Initial conditions in the problem of identification of a voice source / V. N. Sorokin, A. A. Tananykin // Information processes. - 2010. volume 10, No. 1. - p. 1-10.

10. Geraimchuk M. D. Two-stage gyrocompass with high-frequency intensive pitching of the base / M. D. Geraimchuk, Yu. F. Lazarev, P. M. Aksenenko // News of the Cherkasy State Technological University. Ser.: Technical sciences. - 2013. - No. 4. - S. 67-74.

11. Kamke E. Handbook of ordinary differential equations / E. Kamke - M .: Nauka, 1971. -576 p.

12. Kalitkin N. N. Numerical methods / N. N. Kalitkin - S.-Pb., BHVPetersburg, 2014. -592 p. 